\title{
Educational technology: a facilitating instrument for the elderly care
}

\author{
Tecnologia educacional: um instrumento dinamizador do cuidado com idosos \\ Tecnología educacional: un instrumento dinamizador del cuidado de ancianos
}

\section{Rachel da Silva Serejo Cardoso', Selma Petra Chaves Sá', Ana Maria Domingos", Vera Maria Sabóia', Tauan Nunes Maia"', Joviria Marcia Ferreira de Oliveira Padilha', Glycia de Almeida Nogueira' \\ ' Universidade Federal Fluminense, Aurora de Afonso Costa Nursing School. Niterói, Rio de Janeiro, Brazil. "Universidade Federal do Rio de Janeiro, Anna Nery Nursing School. Rio de Janeiro, Brazil. \\ III Instituto Federal do Rio de Janeiro. Niterói, Rio de Janeiro, Brazil.}

\author{
How to cite this article: \\ Cardoso RSS, Sá SPC, Domingos AM, Sabóia VM, Maia TN, Padilha JMFO, et al. Educational technology: \\ a facilitating instrument for the elderly care. Rev Bras Enferm [Internet]. 2018;71(suppl 2):786-92.
}

[Thematic Issue: Health of Older Adults] DOI: http://dx.doi.org/10.1590/0034-7167-2017-0129

Submission: 03-31-2017 Approval: 07-22-2017

\begin{abstract}
Objective: To develop educational technology with caregivers of older people based on the needs, difficulties and concerns related to the elderly care expressed by the caregivers themselves. Method: Research of qualitative nature, with participant observation, based on concepts used by Paulo Freire. Data collection and analysis used the "World Cafe" methodology and the thematic content analysis, respectively. Result: The needs of these caregivers refer to their training and information on aging. The difficulties highlighted are deterrents to quality assistance to older adults, such as: insufficient resources, environmental factor and relationship with the family. The interests are evident in relation to the care and to its more subjective relationship. Final considerations: Educational technologies, printed matter and media, developed along with the caregivers, contribute to orientation and information of caregiver, population and professionals as facilitating instruments, regarding elderly care.
\end{abstract}

Descriptors: Health of Older Adults; Caregivers; Educational Technology; Health Services for Older Adults; Health Education.

\section{RESUMO}

Objetivo: desenvolver tecnologia educacional com cuidadores de idosos a partir de necessidades, dificuldades e interesses manifestados por esses indivíduos quanto ao cuidado com a pessoa idosa. Método: pesquisa de cunho qualitativo, com abordagem participante, orientada por conceitos de Paulo Freire. A coleta e a análise dos dados foram feitas com base nas técnicas do World Café e da análise de conteúdo do tipo temático, respectivamente. Resultado: as necessidades dos cuidadores de idosos se referem a capacitação e informações sobre envelhecimento. As dificuldades apontadas estão nos impeditivos para assistência de qualidade ao idoso, tais como: insuficiência de recursos, fator ambiental e relação com a família. Os interesses são evidentes no tocante à prática do cuidado e em sua relação mais subjetiva. Considerações finais: as tecnologias educacionais, impresso e mídia, desenvolvidas com os cuidadores, contribuem, enquanto instrumentos dinamizadores, para orientação e informação do cuidador, da população e de profissionais sobre o cuidado com o idoso.

Descritores: Saúde do Idoso; Cuidadores; Tecnologia Educacional; Serviços de Saúde para Idosos; Educação em Saúde.

\section{RESUMEN}

Objetivo: Desarrollar tecnología educacional con los cuidadores de ancianos a partir de las necesidades, dificultades e intereses manifestados por dichos cuidadores, relativos al cuidado de personas ancianas. Método: Investigación de carácter cualitativo, con enfoque participante, orientada por los conceptos de Paulo Freire. Para la recolección y el análisis de los datos se utilizaron las técnicas del «World Café» y análisis de Contenido del tipo temático, respectivamente. Resultado: Las necesidades de los cuidadores de ancianos se refieren a su capacitación y a información acerca del envejecimiento. Las dificultades señaladas se encuentran en los impeditivos para asistencia de calidad al anciano, tales como: insuficiencia de recursos, factor ambiental y relación familiar. Los intereses son evidentes respecto a la práctica del cuidado y en su relación más subjetiva. Consideraciones 
finales: Las tecnologías educacionales, impreso y medios, desarrollados con los cuidadores, contribuye en cuanto instrumento dinamizador para orientación e información del cuidador, población y profesionales, frente al cuidado del anciano.

Descriptores: Salud del Anciano; Cuidadores; Tecnología Educacional; Servicios de Salud para Ancianos; Educación en Salud.

\section{CORRESPONDING AUTHOR Rachel da Silva Serejo CardosoＥ-mail: rachelserejo@bol.com.br}

\section{INTRODUCTION}

Brazil is going through a demographic transition influenced by several factors, such as advances in medicine, decrease in birth rate and mortality and increased life expectancy ${ }^{(1)}$. Thus, the age pyramid is being modified, and the number of older people, both absolute and proportional, is increasing over the years ${ }^{(1)}$. These changes generate several economic, political, social and cultural demands for the individual and for society. For these reasons, the aging process is a relevant theme that must be viewed under several prisms.

The aging process can bring several implications for the individuals' quality of life, such as their autonomy and independence in activities of daily living. When these activities are impaired, older adults need support from the family and from the health services system ${ }^{(2)}$. The caregiver, in this scenario, is necessary, as he/she is an individual who provides care, and may or may not be a relative, with or without remuneration, thus being a critical piece to the needs of the older adults, promoting their well-being, security, comfort and especially encouraging their autonomy and independence ${ }^{(3)}$.

Some authors ${ }^{(4)}$ highlight the need for health education activities for caregivers and clarify that they need to have subsidies to provide care, such as, understanding of basic human needs, adaptations and changes that occur throughout life in all dimensions, whether they are biological, psychological, social, cultural and spiritual.

In view of the importance of information and health education for caregivers, and their influence in the care of the older person, an instrument of mediation can help in this process. The educational technology brings this contribution ${ }^{(4)}$.

According to Nietshe et al. ${ }^{(5)}$, educational technology must be understood by implemented processes, based on everyday experiences, aiming at the methodical development of knowledge and know-how to be used with the specific practical purpose. To do so, the educational technology contributes to generating knowledge to be socialized.

The use of educational technology, understood as facilitating tools in promoting a humanized care, enhances the education and guidance of care ${ }^{(6)}$. Therefore, it is of fundamental importance to reflect upon what are the knowledge needed to provide this care to the older adults and how this knowledge is transmitted to professional or family caregiver. In this process, one must consider the reality, the needs, problems and interests of caregivers ${ }^{(6)}$.

However, most studies investigating the use of educational technology for elderly care have a low level of evidence and methodological rigor ${ }^{(6)}$. Therefore, this study is justified by the importance of the use of educational technologies as valuable tool for facilitating learning in an interactive, creative and objective way.

\section{OBJECTIVE}

To develop educational technology with caregivers of older people based on the needs, difficulties and concerns related to the elderly care expressed by the caregivers themselves.

\section{METHOD}

\section{Ethical aspects}

This research was approved on 09/30/2015, by the Ethics Committee (CEP) of the Medical School at the Fluminense Federal University and met the provisions of resolution No. 466 of December 12, 2012, of the National Health Council, which regulates research involving human beings ${ }^{(7)}$. After the explanation of objectives, data collection techniques and that they could withdraw from the survey at any time, the caregivers that agreed to participate in the research signed an informed consent form.

Theoretical-methodological framework and Type of study

This research of qualitative nature, with observant participation is inserted in the educational context and has in the figure of the educator/researcher a component part of the studied scenario. As theoretical/conceptual framework, we used the concepts developed by Paulo Freire ${ }^{(8)}$ : dialogical relationship and problematizing education.

\section{Methodological procedures}

\section{Study scenario}

The scenarios were: Furnas Centrais Elétricas (FUR), in partnership with the Evangelical Institution of social and cultural assistance; and the Health Care Center of the Elderly and their Caregiver (CAS) of the Fluminense Federal University.

\section{Participants of the Study and Data Source}

The caregivers were selected by convenience, being selected 48 caregivers in total, 28 from FUR and 20 from CAS scenarios. To attract caregivers from CAS, a workshop was prepared, disclosed through posters around the community, oral invitation for users of the service and communication to the CAS professionals in staff meeting. The attraction of caregivers from FUR occurred after the contact with the first class of 2015 held in the municipality of Duque de Caxias, Rio de Janeiro. The research project was presented initially, and the caregivers who agreed to participate were invited to stay after the activities proposed for the day.

The inclusion criteria for caregivers from FUR: formal and/or informal caregivers with elementary school. The inclusion criteria for caregivers from CAS: formal and/or informal caregivers regardless of education level. Exclusion criteria: those who did 
not obtain $80 \%$ presence in the meetings of caregivers in both CAS and FUR and caregivers of individuals who are not elderly.

\section{Data collection and organization}

Data collection was based on the guidelines of the "World

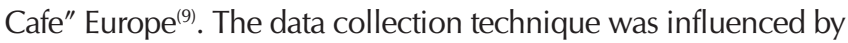
Paulo Freire's concepts ${ }^{(8)}$ of the dialogical relationship and problematizing education that aimed to allow the empowerment of the subject through his/her coparticipation, coauthorship of the production of educational technology. The groups from both scenarios were composed, throughout the collection, by formal and informal caregivers, i.e. in a mixed form. The collection was held in the period between October and December 2015.

To initiate the discussion and meet the goals of the research, semi-structured questions were elaborated regarding the care of older people at home and put on the table, namely: Why did you start the activity of caregivers of older adults? What facilitates the integral care of older adults? What makes the integral care of older adults difficult? What would improve the integral care of older adults? What would you like to know about the integral care of older adults?

The participants could discuss the questions related to the theme, without focusing only on answering the questions. The group from each scenario was subdivided into small groups from 4 to 5 caregivers. The small group answered a question on a table, and the spokesman wrote in these notes in a big sheet of paper. Exhausted the initial discussion, the elements from each group exchanged tables, except the spokesman, and they were challenged to answer a new question, conducting the discussion through addition, or refutation, of the ideas exposed earlier by other subgroups.

After several "rounds of dialogue," the period of sharing of opinions with the whole group began. In these conversations, plenary style, whose goal was to expand the collective knowledge and the possibilities for action, the spokesman of each table presented the results, and the whole group debated the standards and reached, or not, a consensus about the facilitating and hindering factors of the care of older adults and their interests.

\section{Study steps}

The research in CAS occurred in the following steps: 1 meeting for Recruitment of the sample, 4 meeting for Data collection with a week interval between them; 1 meeting for the Collective construction of educational technology, where the participant would give their opinions and suggestions, at this point the group suggested a printed matter and other media in video form for demonstration and guidance of care and 1 meeting of the Final presentation of educational technology, in which caregivers used the educational technology and made evaluations, through an instrument, video and print media, about the purpose of the material, organization, style, appearance and motivation, constituting the validation with the target audience.

In FUR, the following steps were performed: 1 meeting for the Recruitment of the sample 2 meeting for data collection, with 1-week interval between them and 1 meeting for the Presentation of the educational technology, in which caregivers used the educational technology and made suggestions about the purpose of the material, organization, writing style, appearance and motivation both for the video and the printed matter by establishing their validation with the caregivers.

\section{Data analysis}

Data of the groups recorded on the sheets by the spokesperson of each of the tables, were fully transcribed. From this transcript, the material was analyzed according the method of thematic content analysis ${ }^{(10)}$. The thematic classes, categories and subcategories emerged from units of meaning that were identified through the transcript coding and categorizing of information found in the participants' speeches. The categorization resulted in 3 thematic classes, 4 categories and 10 subcategories.

The first thematic class is related to the (1) Needs of caregivers, in which the following categories emerged: Human aging, the necessary knowledge, with the subcategories "Aging, Senescence and senility" and "Requirements from the demands of Alzheimer's Dementia (AD)"; and, the category Caregiver Training with subcategories "Orientation for informal care" and "Training for formal care." In the second thematic class, (2) Difficulties pointed out by the caregivers showed the category Several deterrents to meet the needs of elderly care by caregivers, their respective subcategories: "Environment, Support from family and public authorities" and "insufficient resources." Finally, the third thematic class, which is related to (3) Interests of the caregivers, has as category The care of the caregiver, and its respective subcategories "Basic care" and "Care relations."

\section{RESULTS}

The groups from both scenarios were composed by female caregivers, who in their most had high school education and marital status, stable union or marriage. The only difference between the groups is the age group of the caregivers, which ranges from 40 to 49 years in FUR and from 50 to 59 years in CAS.

\section{Caregivers' needs}

The thematic class (1) was based on the caregivers' needs to discuss aging and its ramifications. It is understood that the caregivers have the perception of aging and the awareness that we are getting old. The perceptions seized include everyday experiences, from the problems experienced within their contexts of care, in which the caregivers signaled fragile knowledge about the aging process.

In the category Human Aging, the necessary knowledge the respondents demonstrated, in the act of caring, concern with the following knowledge: Population aging, through the lines "Because the population has aged," "awareness that we're getting old"; Senescence and senility; exemplified by the line "Prevention: more information of pathological aging and natural diseases"; and needs from the AD demands, observed in the line "To identify the symptoms of the natural aging of the Alzheimer's disease."

When it comes to Caregiver Training, the following aspects were related to the quest for training: guidance for informal care, evidenced in the lines "To have knowledge, to take good care, to do the best because of a family need looking at the 
past aiming at the future, specializing in the present to take care of yourself, to take care of the other" and "I felt like doing the course of caregiver to take care of my mom, because I'm a family caregiver for financial issues, because when she dies, I intend to have a job and also to obtain more knowledge, knowledge does not occupy space"; and, training for formal care, as observed in the lines "Because I work with health and knowledge is necessary in my field" and "Career choice, because I love older people, to add valuable knowledge, to act."

\section{Difficulties pointed out by the caregivers}

This class theme was elaborated based on the lines related to the difficulties of the caregivers when providing humanized care, among them the environmental factor, the support from the family and from the public authorities, regarding the rights of the family and of the older adult, and lack of, not only material, but, above all, financial resources.

Regarding "Several deterrents to meet the needs of elderly care by caregivers," environmental factors, support from family and public authorities, and lack of resources were highlighted. The environment where the older adult stays was mentioned as being worrisome for the caregiver. It should be noted that the caregivers have showed needs of "Good environmental conditions where the older adults are taken care of" and "adaptations in the house and an airy environment."

Concerning the family support, the main deterrents highlighted were "The family life, interacting with the patient and the care," "How to make the family interact to benefit the older adult?", "Lack of support from other members of the family," "To keep the physical and emotional integrity to plan ways of living with the patient and family."

Issues involving older adults, family and caregiver were also observed. After they talked about the relationship between care and family, it became clear that "Older people miss their family" and that "The caregiver needs all the support because he/she is the link between the family and the patient." The affective relationship was also evidenced in the lines: "The family's relationship with the caregiver: the love, affection and especially patience," "Dedication, love from both the family and the professional caregiver."

In addition to the lack of family support, cited by the caregivers as a deterrent to the care, the participants also mentioned as deterrents the lack of support from the public authorities and resources, as evidenced in the lines "The public authorities make the elderly care very difficult because we depend on things and we do not have resources, which hinders the care of the caregiver," "In case of lack of money, government support never arrives...", "To have all the appliances to help us."

Thus, the caregivers pointed out which attitudes, aimed at daily elderly care, the government should take, such as: "To receive a worthy salary and benefit," "Access to mobility rights, accessibility, cultural interaction and all rights of law," "Motivational campaigns by the government X older adults."

\section{Interests of caregivers}

In this thematic class we stand out that the caregivers, in both scenarios, showed interest in the elderly care regarding various dimensions, both in the practical care itself, and in subjective caregiving relationships, assigned to human values, such as empathy and love of neighbor.

Regarding the Care provided by caregivers, concerns over basic care were demonstrated through lines that report concern over hygiene, falls, independence, issues relating to medical advice, nutrition, as it was observed in the lines: "Nutrition: a little salt, sugar, oil, lots of liquid...", "Fall: avoid falling because of the bones," "The locomotion difficulty," "Independence: to let them defend themselves, if they want to eat alone or do any other thing they can...", "To know the medical history of the older adult," "Medication: on time," "To sanitize the private parts," "Hygiene: bath, skin care (to apply oil and sunscreen)," "The care of the patient with probe."

About Care relations, several questions were highlighted by the caregivers, such as: "When the older adult refuses to receive the care of the caregiver?", "Lack of attention to the older adult," "Lack of patience interferes negatively," "Encouragement, communication, relationship with the older adults, confidence, security, to show that they are capable of doing something, that they useful," "The older people cannot think they are a burden," "Social interaction," "Lack of communication," "How to deal with the sexuality of the older adult?".

We noted that the caregivers, in addition to the interests linked to the daily practice of care, are also concerned with the relations that integrate care, more specifically about the relations with the family, communication with the older adults, and increased ties with them, citing values such as love, trust and security.

Regarding the development of educational technology of printed matter and the media, the caregivers submitted questions relating to the organization of the content, seeking something more dynamic that would facilitate the care. After the media and printed matter were constructed collectively, considering the caregivers' views, we could observe that the need for guidance and training has been met, and that this educational technology proved to be a tool of empowerment for the subjects.

The participants considered that the educational materials developed are important for the general population, the caregivers and health professionals as educational instrument, with unanimity on the importance of video and printed matter to the population, considering both instruments as complementary tools.

\section{DISCUSSION}

According to the caregivers' speech, it is necessary to discuss about aging and its dimensions, defining and differentiating the senescence of senility, to clarify the process of natural and pathological aging, and a better understanding for the care and self-care.

Some authors ${ }^{(11-12)}$ claim that AD is a progressive and degenerative disease, generator of multiple demands and high financial cost, it is a form of dementia that affects the older adults and undermines their physical, mental and social integrity, leading to total dependency situations with a care increasingly complex, which can generate multiple demands. The care provided to these people influences the physical, psychic and emotional state of the caregiver, showing that this caregiver, especially a 
familiar one, need continuous psychological support ${ }^{(13)}$. This fact can be seen on the needs from the AD demands reported by the caregivers. Diniz et al. ${ }^{(14)}$ show the need of health education for caregivers of patients with AD. Often, the caregiver is unaware of the proper conduct in relation to the manifestations of the disease and the demands of caring for a weakened older adult. We need to focus on educational aspects that promote a positive effort to help the caregiver to overcome the challenges posed by the situation of misfortune.

Based on the lines of the caregivers, the need for care guidance is notorious. In this sense, Conceição ${ }^{(15)}$ states that caregivers of older adults need some kind of guidance and/or training, regardless of the functional level of the older person and complements by saying that every caregiver should be literate, have physical and mental health, possess notions of minimum care and basic understanding of the human aging process ${ }^{(15)}$. On the other hand, Vieira et al. ${ }^{(16)}$ indicate that elderly care imposes a reality to the caregiver, characterized by knowledge and practices built from experiences determined by the situation, influenced by sociocultural factors, in an intuitive way and based on previous experiences, beliefs and through the exchange of information with other people and/or support groups.

Given this, the caregivers need education and guidance, because taking care of a dependent or independent older adult, involves complex tasks, permeated with difficulties in different ways, which can be aggravated by the shortage of preparation and caregiver information. The little information and guidance regarding the older adult can generate insecurity and fears, which constitute the unpreparedness of this caregiver, generating damages such as physical and emotional damage ${ }^{(16)}$. By analyzing the caregivers' speeches, we realize the importance of training for exercising this occupation. Other authors ${ }^{(3,15-16)}$ also reinforce the need for guidance and preparation of both the formal and informal caregiver.

The environment where the older adult lives was cited as being worrisome for the caregiver, and this is a factor that also concerns the professionals who assist the older adults ${ }^{(17)}$. This concern should not occur only in environments for older people with few limitations, but in the environment where healthy older adults live as well. It is noteworthy that the senses and emotions that this environment represents for the older adult are also valued ${ }^{(17)}$. Thus, it is crucial that the caregiver is encouraged to maintain an environment that considers the limitations of the older adults, even because, considering their functional capacity and autonomy, environmental adaptations favor the maintenance of the independence and autonomy of the older person, thus preventing the abandonment of activities of daily life and allowing their personal growth ${ }^{(18)}$, also noticed by the caregivers of this study.

Regarding the family of the older adult, in the caregivers' answers, we observed that within the family context there are different views with this same theme, such as: the family's relationship with the older adult, the family's relationship with the caregiver and the caregiver in the family context. Couto et al. ${ }^{(19)}$ reinforce that the main source of social support that encourages the maintenance of the older adult's physical and mental health is the family. Ciosak et al. ${ }^{(20)}$ reported that the family develops physically, emotionally, mentally and spiritually where interpersonal relations are established, permeated by crises and conflicts and that, at the time of disease, family members need to be supported, with the aim of overcoming, adapting and growing self-help and caregiving relationships. There is the need for support and interaction of all family members in the care of the older adult.

We observed that the caregivers understand that the public authorities can help and also hinder the care, and they highlight the importance of its participation and campaigns for the older adults. Regarding the difficulties listed by the caregivers, because of the lack of financial resource and support services offered by the State, the families end up being responsible for the care, being, most often, unprepared for such activity. One must consider not only the quality of the service offered to the older adult by the family members, but also the impact that these tasks have on the quality of life of caregivers, older adults and their families ${ }^{(21)}$. However, if we want our seniors to remain in their family life with a high standard of quality care, the caregivers should be targets of guidance, training and supervision ${ }^{(21)}$.

Interests related to the basic care of the older adult include: nutrition; guidance regarding physical activity; prevention of falls; locomotion difficulty; inclusion in society; autonomy and independence; organization of activities of daily life, through the construction of a caregiver's journal; guidance regarding medication; care of the general hygiene and of the patient with probe. Corroborating with these findings, the authors ${ }^{(04,22)}$ showed in their study an interest in health education, which arose from the caregivers' needs and difficulties.

Regarding the care relationship, it is interesting to note that some of the interests discussed by the participants are in the relations that the caregiver has with the older adult. The care, according to Boff ${ }^{(23)}$, is seen in such an anthological way, beyond attitudes and actions of human beings, being prior to human attitudes and, therefore, is included in all situations and actions. Savieto and Leão ${ }^{(24)}$, on the other hand, mention the theory of human caring by Jean Watson to discuss care. The humanized care requires reverence for life and the presence of non-paternalistic values that can be shown through the development of autonomy and free choice, strengthening thus, self-knowledge, self-control, and the willingness to self-healing.

The caregivers' interests, regarding caregiving relationships, are demonstrated through their speech. Concerns about how to proceed with the older adult who refuses to receive the care of the caregiver, the lack of family love, lack of attention, love, how to have more patience, how to deal with the lack of communication, and how to deal with the sexuality of the older adult were highlighted. For Nascimento et al. ${ }^{(25)}$, the assistance provided to the older adult, whether professional or familiar, must be based on the ethical principle so the care is provided with respect, affection and sensibility, in order not only to cure the disease, but to promote the individual's health. Thus, ethics involves much more than legislation and standards that pervade the care, it requires that the caregiver reflect on his/her practice, whether professional or not, having the ethics as an influence on decision-making related to the 
older adult, considering, especially, the autonomy and respect for the older person ${ }^{(25)}$.

The development of educational technology was able to promote the awareness of the real situation, and the praxis for caring, overcoming the vision of a purely technical and abstract educational technology for caregivers. In this sense, Freire $^{(8)}$ claims that these two conditions make the individuals pass from the naive curiosity to the epistemological curiosity state, becoming empowered and able to intervene in reality, in order to transform their practice and society.

\section{Limitations of the study}

We considered as a study limitation the number of caregivers participating in the last meeting, when the educational technology was validated by the target audience. Several participants, in this last meeting, could have brought more information and contributions to the creation of the educational material.

\section{Contributions to the area of nursing and public health}

In view of the low production of studies that developed educational technology for caregivers of older adults, this study brings relevant contributions to the field of gerontogeriatric nursing and gerontological education with family and professionals caregivers and society. In this sense, the educational technology developed is a facilitating instrument for the promotion of health care, prevention of complications and diseases, development of skills to encourage autonomy and independence in the older adult. Thus, this study also contributes to the teaching and research in health, since the educational technology developed is available, with free access, through virtual means.

\section{FINAL CONSIDERATIONS}

By describing the content considered essential for caregivers we realized that there are educational demands that have prominent position, mainly in health education. The main guidance needs pointed out by the caregivers were related to their training, aging and its consequences. The difficulties listed were those relating to deterrents to meet the needs of care by the caregivers, such as: environment, lack of resources, support from the family and from public authorities. The interests raised by the caregivers were related to knowledge of care with the elderly person in two dimensions: the practical care and the caregiving relationships, showing that patience, love, and empathy interfere in caregiving relationships.

We concluded that the development, with the caregivers, of the educational technologies, printed materials and the media in general, contributed to guidance and information concerning elderly care and the decision-making of the caregiver. It is dynamic instrument that can be used by the caregiver, by the population in general and by the nurse while a health team member is mediating his/her educational practice with caregivers. Therefore, we suggest new intervention studies that use educational technology geared for caregivers of older adults aiming at the sociodemographic and epidemiological reality in Brazil now and in the future.

\section{REFERENCES}

1. Silva A, Dal Pra KR. Envelhecimento populacional no Brasil: o lugar das famílias na proteção aos idosos. Argumentum[Internet]. 2014[cited 2016 Jun 09];6(1):99-115. Available from: http://periodicos.ufes.br/argumentum/article/viewFile/7382/5754

2. Carvalho JA, Escobar KAA. Cuidador de idosos: um estudo sobre o perfil dos cuidadores de idosos do programa de assistência domiciliar (PAD) da Associação dos Aposentados e Pensionistas de Volta Redonda. AAP-VR. Rev Cientif ITPAC[Internet]. 2015[cited 2016 Jun 09];8(1):01-13. Available from: http://www.itpac.br/arquivos/Revista/76/Artigo_6.pdf

3. Araujo JS, Vidal GM, Brito FN, Gonçalves DCA, Leite DKM, Dutra CDT, et al. Perfil dos cuidadores e as dificuldades enfrentadas no cuidado ao idoso, em Ananindeua, PA. Rev Bras Geriatr Gerontol[Internet]. 2013[cited 2016 Jun 09];16(1):149-58. Available from: http://www.scielo.br/pdf/rbgg/v16n1/a15v16n1.pdf

4. Braccialli LMP, Bagagi OS, Sankako NA, Araujo RCT. Qualidade de vida de cuidadores de pessoas com necessidades especiais. Rev Bras Educ Esp [Internet]. 2012[cited 2016 Jun 09];18(1):113-26. Available from: http://www.scielo.br/pdf/rbee/v18n1/ a08v18n1.pdf

5. Nietsche EA, Lima MGR, Rodrigues MGS, Teixeira JA, Oliveira BNB, Motta CA, et al. Tecnologias Inovadoras do cuidado em enfermagem. Rev Enferm UFSM [Internet]. 2012 [cited 2016 Jun 09];2(1):182-9. Available from: https://periodicos.ufsm.br/reufsm/ article/view/3591/3144

6. Cardoso RSS, Bom FS, Maia TN, Alves Junior ED, Sá SPC. Tecnologia educacional desenvolvida ou utilizada para o cuidador de idosos: uma revisão integrativa. Rev Enferm UFPE[Internet]. 2015 [cited 2016 Jun 09];9(10):1565-71. Available from: http://www. revista.ufpe.br/revistaenfermagem/index.php/revista/article/view/7991/pdf_9250

7. Brasil. Ministério da Saúde. Conselho Nacional de Saúde. Resolução nº 466, de 12 de dezembro de 2012. Aprova as diretrizes e normas regulamentadoras de pesquisas envolvendo seres humanos [Internet]. Diário Oficial da União. Brasília, n. 12, p. 59, 13 jun. 2013 [cited 2017 Nov 20]. Seção 1. Available from: http://bvsms.saude.gov.br/bvs/saudelegis/cns/2013/res0466_12_12_2012. html

8. FREIRE P. Pedagogia da autonomia: saberes necessários à prática educativa. São Paulo: Paz e terra; 2014.

9. Brown J, Isaacs D. The world café: shaping our futures through conversations that matter. São Francisco: Berrett Koehler Publishers; 
2005.

10. Bardin L. Análise de conteúdo. Lisboa: Edições Setenta; 2011.

11. Luzardo AR, Gorini MIPC, Silva APSS. Características de idosos com doença de Alzheimer e seus cuidadores: uma série de casos em um serviço de neurogeriatria. Texto Contexto Enferm [Internet]. 2006[cited 2016 Jun 09];15(4):587-94. Available from: http:// www.scielo.br/pdf/tce/v15n4/v15n4a06

12. Pinto MF, Barbosa DA, Ferreti CEL, Souza LF, FRAM DS, Belasco AGS. Qualidade de vida de cuidadores de idosos com doença de Alzheimer. Acta Paul Enferm [Internet]. 2009[cited 2016 Jun 09];22(5):652-7. Available from: http://www.scielo.br/pdf/ape/ v22n5/09.pdf

13. Leite CDSM, Menezes TLM, Lyra EVV, Araújo CMT. Conhecimento e intervenção do cuidador na doença de Alzheimer: uma revisão da literatura. J Bras Psiquiatr[Internet]. 2014[cited 2016 Jun 09];63(1):48-56. Available from: http://www.scielo.br/pdf/ jbpsiq/v63n1/047-2085-jbpsiq-63-1-0048.pdf

14. Diniz MAA, Monteiro DQ, Gratao ACM. Educação em saúde para cuidadores informais de idosos. Saúde Transf Soc [Internet]. 2016[cited 2016 Jun 09];7(1):28-40. Available from: http://incubadora.periodicos.ufsc.br/index.php/saudeetransformacao/article/ viewFile/3606/4532

15. Conceição LFS. Saúde do idoso: orientações ao cuidador do idoso acamado. Rev Med [Internet]. 2010[cited 2016 Jun 09];20(1):8191. Available from: http://www.observatorionacionaldoidoso.fiocruz.br/biblioteca/_artigos/199.pdf

16. Vieira CPB, Fialho AVM, Freitas CHA, Jorge MSB. Prática educativa para autonomia do cuidador informal de idosos. Rev Bras Enferm [Internet]. 2011[cited 2016 Jun 09];64(3):570-9. Available from: http://www.scielo.br/pdf/reben/v64n3/v64n3a23.pdf

17. Mendes FRC, Corte B. O ambiente da velhice no país: por que planejar? Rev Kairós Gerontol[Internet]. 2009 [cited 2016 Jun 09];12(1):192-212. Available from: http://revistas.pucsp.br/index.php/kairos/article/view/2787/1822

18. Neves ALC, Melo ACR, Mendonça BOM, Monteiro B, Nogueira DS, Barros EJ, et al. FATORES de risco relacionados à queda entre idosos em uma instituição pública de um município do estado de Goiás. Rev Fac Montes Belos [Internet]. 2016 [cited 2016 Dec 09];9(1):122-73. Available from: http://revista.fmb.edu.br/index.php/fmb/article/view/216/193

19. Couto AM, Castro EAB, Caldas CP. Vivências de ser cuidador familiar de idosos dependentes no ambiente domiciliar. Rev Rene [Internet]. 2016[cited 2016 Dec 09];17(1):76-85. Available from: http://200.129.29.202/index.php/rene/article/view/2624/2011

20. Ciosak SI, Braz E, Costa MFBN, Nakano NGR, Rodrigues J, Alencar RA, et al. Senescence and senility: the new paradigm in primary health care. Rev Esc Enferm USP [Internet]. 2011[cited 2016 Jun 09];45(2):1763-8. Available from: http://www.scielo.br/ pdf/reeusp/v45nspe2/en_22.pdf

21. Kuchemann BA. Envelhecimento populacional, cuidado e cidadania: velhos dilemas e novos desafios. Soc Estado [Internet]. 2012[cited 2016 Jun 09];27(1):165-80. Available from: http://www.scielo.br/pdf/se/v27n1/09.pdf

22. Barbosa AL, Cruz J, Figueiredo D, Marques A, Sousa L. Cuidar de idosos com demência em instituições: competências, dificuldades e necessidades percepcionadas pelos cuidadores formais. Psicol Saúde Doenças [Internet]. 2011[cited 2016 Jun 09];12(1):119-29. Available from: http://www.scielo.mec.pt/pdf/psd/v12n1/v12n1a08.pdf

23. Boff L. Saber cuidar: ética do humano, compaixão pela terra. Rio de Janeiro: Vozes; 1999.

24. Savieto RM, Leão ER. Assistência em Enfermagem e Jean Watson: uma reflexão sobre a empatia. Esc Anna Nery Rev Enferm[Internet]. 2016[cited 2016 Dec 09];20(1):198-202. Available from: http://www.scielo.br/pdf/ean/v20n1/1414-8145-ean-20-01-0198.pdf 